\title{
A New Live-Bearing Species of Scincid Lizard (Reptilia: Scincidae) from New Caledonia, Southwest Pacific ${ }^{1}$
}

\author{
Ross A. Sadlier, ${ }^{2}$ Sarab A. Smith, ${ }^{3,5}$ Anthony Whitaker, ${ }^{4}$ and Aaron M. Bauer ${ }^{3,6}$
}

\begin{abstract}
A new species of skink, Kanakysaurus zebratus, is described from the ultramafic Massif de Kopéto and Massif de Koniambo on the northwestern coast of Grande Terre, New Caledonia. Although this new species is similar in overall appearance to its congener K. viviparus from the far northwest of Grande Terre and the Îles Belep, it can be distinguished by features of scalation and coloration. It is also identified as being genetically distinct from and reciprocally monophyletic with respect to populations of $K$. viviparus from Rivière Néhoué (type population), the Iles Belep, and a recently discovered population from Sommet Poum (reported here for the first time). The population of Kanakysaurus on Dôme de Tiébaghi (5 km southeast of Rivière Néhoué) is problematic: in morphology it is closest to $K$. viviparus, but DNA sequence data group part of the population with $K$. viviparus and part with K. zebratus, n. sp. On Kopéto the new species was found only in maquis shrubland at $500-1,000 \mathrm{~m}$ in elevation and on Koniambo in Gymnostoma-dominated closed forest at $700 \mathrm{~m}$. Adult females collected on the Massif de Kopéto in February during the height of the wet season had well-developed embryos, confirming a live-bearing mode of reproduction for the new species, and for the genus as a whole. The summit area of Kopéto is the site of a large nickel mine and substantial portions of the known range of the new species are projected to be cleared to extract nickelbearing ore in the future; extensive development for nickel mining is also forecast in the immediate future for Koniambo. Because of the apparently restricted range and projected degradation of habitat of this new species, it is here regarded as assignable to IUCN Red List Category Endangered and considered a high priority for conservation management.
\end{abstract}

The island of New Caledonia has been identified as a biodiversity hot spot of inter-

\footnotetext{
${ }^{1}$ Manuscript accepted 24 January 2008.

2 Section of Herpetology, Australian Museum, 6 College Street, Sydney 2000, New South Wales, Australia (e-mail: ross.sadlier@austmus.gov.au).

${ }^{3}$ Department of Biology, Villanova University, 800 Lancaster Avenue, Villanova, Pennsylvania 19085.

${ }^{4}$ Whitaker Consultants, 270 Thorpe-Orinoco Road, Orinoco, R.D. 1, Motueka 7196, New Zealand (e-mail: whitaker@ts.co.nz).

${ }^{5}$ Current address: School of Science and Primary Industries, Charles Darwin University, Darwin 0909, Northern Territory, Australia (e-mail: sarah.smith@cdu .edu.au).

${ }^{6}$ Corresponding author: (phone: 1-610-519-4857; fax: 1-610-519-7863; e-mail: aaron.bauer@villanova.edu).
}

Pacific Science (2009), vol. 63, no. 1:123-136

(C) 2009 by University of Hawai'i Press

All rights reserved national standing (Myers 1988, 1990, Mittermeier et al. 1996, 1999, Myers et al. 2000) and as one of the high-priority regions for conservation in the world. Its recognition as such stems from the exceptional diversity and level of endemism of the island's flora, particularly the humid forest $(>2,100$ taxa with $83 \%$ endemism) and the maquis minier, a shrubland vegetation mainly restricted to ultramafic substrates $(>1,200$ taxa with $90 \%$ endemism) (Jaffré et al. 2001).

The New Caledonian lizard fauna consists solely of skinks and geckos, with the number of described scincid and diplodactylid species in genera endemic to New Caledonia currently standing at approximately 80 , with many additional species waiting to be described. The skinks belong to the essentially Australasian Eugongylus group, and all except three species in the two widespread genera 
(Emoia Gray and Cryptoblepharus Wiegmann) are part of an endemic New Caledonian radiation comprising 13 genera (Smith et al. 2007). Half of the 48 taxa of endemic skinks currently recognized have been described in the past $10 \mathrm{yr}$. This dramatic increase in both species richness and generic diversity of scincid fauna has resulted from extensive laboratory-based research investigating phylogenetic relationships using DNA sequence data (Smith et al. 2007, Sadlier et al. In press) and from extensive field research in recent years. However, the recent discovery of many new taxa in the field and data derived from ongoing molecular phylogenetic projects indicates that the number of species will increase by at least a further $35 \%$ (Bauer and Jackman 2006).

In particular, fieldwork undertaken on the ultramafic massifs along the west coast from Massif du Boulinda in the south to Sommet Poum in the far north of the island (Whitaker et al. 2004) and on other ultramafic mountains in the central regions of the island has resulted in the discovery of a number of new skink and gecko species, many of them endemic to single massifs. Most of the new species of skinks are localized endemics on these mountains-some are restricted to high-elevation humid forests (e.g., Nannoscincus manautei Sadlier, Bauer, Whitaker \& Smith; N. garrulus Sadlier, Bauer \& Smith; Marmorosphax taom Sadlier, Smith, Bauer \& Whitaker; M. boulinda Sadlier, Smith, Bauer \& Whitaker), and others occur in forest and/ or maquis habitats, often over a broader altitudinal range (e.g., Lioscincus vivae Sadlier, Bauer, Whitaker \& Smith; Celatiscincus similis Sadlier, Smith \& Bauer). Similar patterns of localized endemism are found in geckos (Whitaker et al. 2004, Bauer et al. 2006a,b).

The uniqueness of the lizard fauna on the central and northwestern ultramafic massifs indicates a complex history for both the maquis shrubland and high-elevation humid forests to produce the level of regional microendemism recorded: four species appear to be endemic to Mount Taom and three to the Massif de Kopéto, and most other less well-studied massifs in the region have at least two endemic lizards. This field research has also revealed a high level of lizard species richness for these massifs, particularly in the maquis shrublands, with 13 taxa recorded from mid- to high-elevation maquis on the Massif de Kopéto and 10 from high-elevation maquis on Mount Taom. In contrast the lizard fauna in the maquis shrubland on the southern ultramafic block appears to be relatively depauperate, with just seven species recorded collectively from sites in the extensively surveyed maquis shrubland in the region of Forêt Nord in the far south of the island (Sadlier and Shea 2004, 2006).

The central and northwestern ultramafic massifs are subject to a range of pressures that have degraded, or threaten to degrade, the small areas of habitat in which these highly restricted lizard species are found. Mining for nickel occurs on all the major ultramafic massifs on the northwestern coast and some of the smaller massifs. The size of these operations varies, and some are extensive and the level of development is escalating. None of the maquis shrubland or high-elevation humid forest on ultramafic massifs in the Province Nord is formally protected. These massifs are of high conservation significance for the lizard fauna of New Caledonia, and the reservation and management of appropriate areas of habitat is urgently required.

At the request of Sociéte le Nickel (SLN), selected areas on the upper part of Massif de Kopéto were surveyed to detect the possible presence of lizard species of conservation significance. During the course of this work a new species in the recently erected genus $\mathrm{Ka}$ nakysaurus was discovered in maquis shrubland at several sites across the massif from mid- to high elevation. This same species was later located on Massif de Koniambo during the course of survey work undertaken for Koniambo Nickel SAS. In overall morphology (size, shape, scalation) and pattern of coloration the new species is very similar to its recently described congener, Kanakysaurus viviparus, and also shares a live-bearing mode of reproduction.

Additional field research on Sommet Poum in the far north of Grande Terre, also at the request of SLN, has led to the dis- 
covery of a new location for $K$. viviparus, an endangered species previously known from just four populations (Sadlier et al. 2004). On Sommet Poum its habitat included maquis shrubland on "laterite cuirasse," a habitat from which it has not previously been recorded.

\section{MATERIALS AND METHODS}

\section{Morphology}

Standardized collection abbreviations used are as follows: AMS (Australian Museum, Sydney), CAS (California Academy of Sciences, San Francisco), and MNHN (Muséum National d'Histoire Naturelle, Paris). The following characters were scored for each specimen where possible: snout to vent length, measured from tip of snout to caudal edge of anal scales; axilla to groin distance, measured from middle of base of the forelimb to middle of base of hindlimb; forelimb to snout length, measured from tip of snout to middle of base of forelimb; hindlimb length, measured from middle of base of hindlimb to tip of fourth toe including nail; tail length, measured from caudal edge of anal scales to tip of tail, on complete original tails only. Body measurements are expressed as percentages of snout to vent length (SVL) in the taxon accounts.

Head scalation generally follows Taylor (1935) as described and figured by Sadlier (1986). For characters used in Table 1 the abbreviation is given in parentheses: midbody scale rows (MBR), number of longitudinal scale rows around body counted midway between axilla and groin; dorsal scale rows (DSR), number of scales in a row from first scale posterior to parietal scale to last scale at the level of vent opening; fourth finger (FFS) and toe (FTS) scales, number of dorsal scales on fourth digit of hand and foot, distal scale contains claw and basal scale broadly contacts adjacent basal scale of third finger or toe; fourth finger (FFL) and toe (FTL) lamellae, number of ventral scales on fourth digit of hand and foot, distal scale contains claw and basal scale is last largely undivided scale at a point level with intersection of third and fourth digits. Bilaterally scoreable scalation characters were scored on both sides and the mean value used; in the holotype description these values are presented as left/right values. Interpopulational meristic values were compared using $t$-tests.

Specimens were $\mathrm{x}$-rayed for determining the number of premaxillary teeth, presacral and postsacral vertebrae, and phalangeal formula for the manus and pes; other skeletal details were determined by dissection.

\section{Molecular Phylogenetics}

Genomic DNA was extracted, purified, and sequenced from $95-100 \%$ ethanol-preserved liver samples of Kanakysaurus from Massif de Kopéto, Massif de Koniambo, Sommet Poum, Rivière Néhoué, and Dôme de Tiébaghi using protocols published by Sadlier et al. (2004). Mitochondrial ND2 (514bp) and nuclear RAG1 (830bp) were added to an existing data set (Sadlier et al. 2004), which was analyzed using maximum parsimony (MP) and Bayesian inference. Based on prior, higher-order studies of relationship among New Caledonian skinks (Smith et al. 2007), Marmorosphax spp. were used as outgroup taxa.

RESULTS

\section{Systematics}

The genus Kanakysaurus (Sadlier et al. 2004) was recently proposed to accommodate the new species $K$. viviparus, described from the far northwest of Grande Terre, and from Île Art and Île Pott in the Îles Belep. At that time an extensive combination of apomorphic character states diagnosed the genus. Most of these characters still serve to diagnose the genus inclusive of the new species described below; however, one unusual character, the degree of separation or contact between the parietal scales, shows variation between the two species. The modified diagnosis for the genus now is as follows: supranasal scale or postnasal suture absent; subocular scale row complete; primary temporal scales usually two; lower secondary temporal scales 
TABLE 1

Differences in Number of Midbody Scale Rows (MBR), Dorsal Scale Rows (DSR), Fourth Finger (FFS) and Toe (FTS) Scales, and Fourth Finger (FFL) and Toe (FTL) Lamellae between Samples of Kanakysaurus zebratus from Massif de Kopéto, Kanakysaurus sp. from Dôme de Tiébaghi, and Kanakysaurus viviparus from Rivière Néhoué and Sommet Poum

\begin{tabular}{|c|c|c|c|c|}
\hline Character $^{a}$ & $\begin{array}{l}\text { K. zebratus } \\
\text { Kopéto } \\
(n=11)\end{array}$ & $\begin{array}{c}\text { Kanakysaurus sp. } \\
\text { Tiébaghi } \\
(n=3)\end{array}$ & $\begin{array}{l}\text { K. viviparus } \\
\text { Néhoué } \\
(n=17)\end{array}$ & $\begin{array}{c}\text { K. viviparus } \\
\text { Poum } \\
(n=6)\end{array}$ \\
\hline \multicolumn{5}{|l|}{ MBR } \\
\hline Range & $38-40$ & 38 & $38-40$ & $38-42$ \\
\hline $\begin{array}{l}\text { Mean } \pm \mathrm{SD} \\
t=0.43, \mathrm{df}=26, P<.671\end{array}$ & $38.6 \pm 0.93$ & & $38.7 \pm 0.98$ & $40.0 \pm 1.26$ \\
\hline \multicolumn{5}{|l|}{ DSR } \\
\hline Range & $72-81$ & $66-69$ & $65-72$ & $66-70$ \\
\hline $\begin{array}{l}\text { Mean } \pm \text { SD } \\
t=-7.58, \mathrm{df}=26, P<.000\end{array}$ & $75.7 \pm 2.69$ & $67.0 \pm 1.73$ & $69.2 \pm 1.85$ & $68.7 \pm 1.51$ \\
\hline \multicolumn{5}{|l|}{ FFS } \\
\hline Range & $10-11$ & $9-11$ & $9-11$ & $9-10$ \\
\hline $\begin{array}{l}\text { Mean } \pm \mathrm{SD} \\
t=-1.603, \mathrm{df}=26, P=.121\end{array}$ & $10.3 \pm 0.34$ & $9.6 \pm 0.89$ & $9.9 \pm 0.69$ & $9.7 \pm 0.52$ \\
\hline \multicolumn{5}{|l|}{ FFL } \\
\hline Range & $16-20$ & $14-17$ & $13-17$ & $14-16$ \\
\hline $\begin{array}{l}\text { Mean } \pm \mathrm{SD} \\
t=-6.254, \mathrm{df}=26, P=.000\end{array}$ & $17.5 \pm 1.18$ & $15.8 \pm 1.30$ & $15.2 \pm 0.79$ & $15.2 \pm 0.52$ \\
\hline \multicolumn{5}{|l|}{ FTS } \\
\hline Range & $15-18$ & $14-15$ & $14-16$ & $14-17$ \\
\hline $\begin{array}{l}\text { Mean } \pm \mathrm{SD} \\
t=-6.688, \mathrm{df}=26, P=.000\end{array}$ & $16.7 \pm 0.90$ & $14.4 \pm 0.55$ & $14.8 \pm 0.75$ & $15.7 \pm 1.21$ \\
\hline \multicolumn{5}{|l|}{ FTL } \\
\hline Range & $31-34$ & $26-29$ & $26-32$ & $28-31$ \\
\hline $\begin{array}{l}\text { Mean } \pm \text { SD } \\
t=-6.244, \mathrm{df}=26, P=.00\end{array}$ & $32.3 \pm 1.17$ & $27.6 \pm 1.14$ & $28.7 \pm 1.62$ & $29.3 \pm 0.88$ \\
\hline
\end{tabular}

${ }^{a} t$ values relate to independent $t$-tests between samples from the type localities (Kopéto and Néhoué) for each character.

usually two; parietal scales either failing to contact behind the interparietal (K. viviparus) or usually in narrow contact (K. zebratus [Figure 1]); lower eyelid with an obvious centrally located, semitransparent disk; ear lobules barely distinguishable from blunt conical scales around upper, lower, and posterior edges of ear opening; first and second pair of chinshields transversely enlarged, with the first pair in broad contact, members of the third pair divided such that five scales separate those members bordering the labials. Both species also share a live-bearing mode of reproduction.

Kanakysaurus zebratus Sadlier, Smith, Whitaker \& Bauer, n. sp.

Figures 1-3
TYPE MATERIAL: Holotype: MNHN 2006.0393 (formerly ams R167239), $1.5 \mathrm{~km}$ SW Mt. Tiaoué, Massif de Kopéto, Province Nord, New Caledonia, $21^{\circ} 11^{\prime} 02.1^{\prime \prime} \mathrm{S}, 164^{\circ}$ $59^{\prime} 17.8^{\prime \prime}$ E, elevation $740 \mathrm{~m}$, collected by A. H. Whitaker and V. A. Whitaker, 6 March 2006. Paratypes: Ams R167220-24, R167229, Cas 233598, 6 km NW Mt. Tiaoué, Massif de Kopéto, $21^{\circ} 10^{\prime} 11.0^{\prime \prime} \mathrm{S}, 164^{\circ} 59^{\prime} 30.0^{\prime \prime} \mathrm{E}$, elevation $850 \mathrm{~m}$; AMs R167234, $1.2 \mathrm{~km} \mathrm{SE}$ Mt. Vert, Massif de Kopéto, 21 ${ }^{\circ} 10^{\prime} 21.6^{\prime \prime} \mathrm{S}$, $165^{\circ} 02^{\prime} 19.0^{\prime \prime} \mathrm{E}$, elevation $780 \mathrm{~m}$; AMS R167240, 2 km E Mt. Vert, Massif de Kopéto, $21^{\circ} 10^{\prime} 11.6^{\prime \prime} \mathrm{S}, 165^{\circ} 02^{\prime} 56.4^{\prime \prime} \mathrm{E}$, elevation $480 \mathrm{~m}$; AMS R167245, CAS 233599, Plateau between Rivière Salée and Ouénipa, Massif de Kopéto, $21^{\circ} 12^{\prime} 08.0^{\prime \prime} \mathrm{S}, 165^{\circ} 01^{\prime}$ $04.4^{\prime \prime}$ E, elevation $540 \mathrm{~m}$. All paratypes col- 
lected by A. H. Whitaker and V. A. Whitaker between 28 February and 8 March 2006.

ADDITIONAL SPECIMENS EXAMINED: AMS R168063, R168069-70, ridge between Creek Taléa and Rivière Pandanus, Massif de Koniambo, Province Nord, New Caledonia, $20^{\circ}$ $59^{\prime} 43^{\prime \prime} \mathrm{S}, 164^{\circ} 47^{\prime} 26^{\prime \prime} \mathrm{E}$, elevation $700 \mathrm{~m}$, collected by A. H. Whitaker and R. A. Sadlier between 2 and 5 July 2007.

ETYMology: The species epithet is a masculine adjective and refers to the bold, zebra-like stripes that are particularly pronounced in the subadults and juveniles of the species.

DIAGNosis: Kanakysaurus zebratus, n. sp., can be distinguished from its congener $K$. viviparus by having more dorsal scales $(72-81$ versus 65-74) and in females, subadults, and juveniles a pattern of broad dark bands (4-5 scales wide at middorsum) across the body that are wider than the alternating pale interspaces, whereas the dark dorsal bands across the body in $K$. viviparus are narrower (1-3 scales wide at middorsum) and not substantially wider than alternating pale interspaces. A comparison of fourth finger lamellae, fourth toe scales, and fourth toe lamellae also revealed significant differences between the two species (see Table 1), but overlap in the range of these characters makes them of limited use in unequivocally diagnosing the two species from each other.

DESCRIPTION: The species is described from two adult males and five adult females (67-72 mm SVL), two subadults (43.5-56.5 $\mathrm{mm}$ SVL), and two juveniles (42 $\mathrm{mm} \mathrm{SVL).}$ Measurements are given only for adults; otherwise description is based on all specimens except where indicated.

Measurements: Size 66-72 mm SVL; distance from axilla to groin $52.2-55.6 \%$ SVL $(\bar{x}=54.1)$; distance from forelimb to snout $37.5-42.0 \%$ SVL $(\bar{x}=40.1)$; hindlimb length $35.4-37.9 \%$ SVL $(\bar{x}=48.8)$; tail length of individual with most complete tail 147\% SVL.

Scalation (Figure 1): Prefrontals large, narrowly to moderately separated; frontal longer than wide; frontoparietals divided; interparietal distinct; parietals in point to moderate contact behind interparietal, rarely separated $(n=1)$, parietals each bordered by
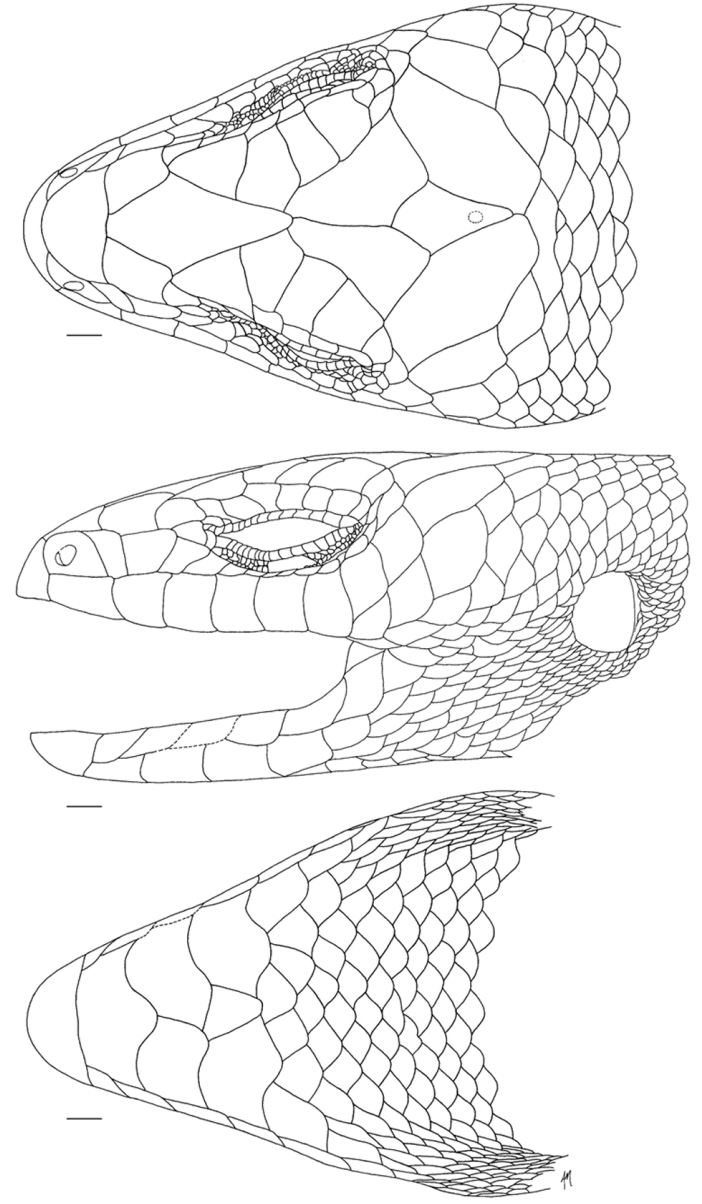

Figure 1. Dorsal (top), lateral (middle), and ventral (bottom) views of the head of holotype of Kanakysaurus zebratus, n. sp. (MNHN 2006.0393). Scale bar $=1 \mathrm{~mm}$.

a transversely elongate upper secondary temporal scale and three smaller scales, two of which are slightly larger in size than adjacent body scales and another larger scale (sometimes divided) that lies behind interparietal and between (and contacting) both parietals; primary temporals usually two, the lower positioned partly between last two upper labials; upper secondary temporal single; lower secondary temporals two; tertiary temporals two $(41 \%)$ or three; postlabials two, rarely fused to form a single scale $(5 \%)$ in that region; nasals moderately large, moderately to widely separated; two loreals, anterior consid- 


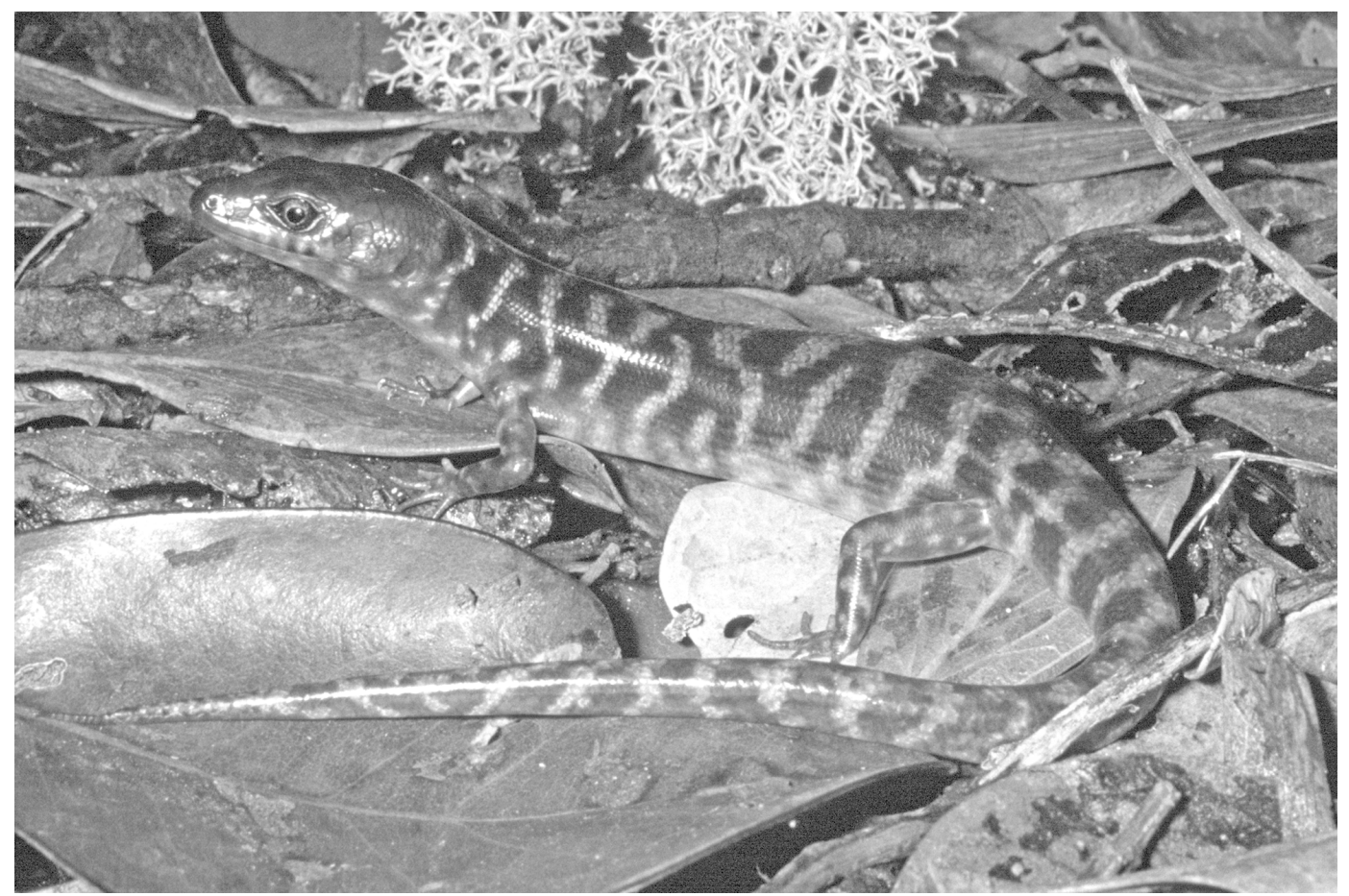

Figure 2. Adult female holotype (mNHn 2006.0393) of Kanakysaurus zebratus, n. sp., in life.

erably narrower than high; supraciliaries 7 $(90 \%)$, rarely 8 or 9 , fourth supraciliary usually noticeably larger than those preceding and interdigitating between first and second supraoculars; upper labials 7 with fifth positioned below eye and separated from lower eyelid by a complete row of 8-10 (usually 9$48 \%$ ) subocular scales; lower labials 6, first two contacting postmental; chinshields three, first and second pair of chinshields transversely enlarged with members of first pair in broad contact and second pair separated by one scale, members of third pair divided such that usually five scales separate those members bordering labials, all chin scales flush with lower labials.

Lower eyelid with an obvious, centrally located, semitransparent disk. Ear opening moderately large, with no obvious enlarged lobules at edges, only a series of small, rounded scales along anterior edge of ear.

Body scales with $3-5$ very faint keels dorsally and 3-4 weaker keels laterally, failing to interrupt posterior edge of scale; midbody scale rows $38-40(\bar{x}=38.5, \mathrm{SD}=0.93)$; dorsal scale rows $72-81(\bar{x}=75.7, \mathrm{SD}=2.69)$; scales on top of fourth finger $10-11(\bar{x}=$ $10.3, \mathrm{SD}=0.34$ ); lamellae beneath fourth finger $16-20(\bar{x}=17.5, \mathrm{SD}=1.18)$; scales on top of fourth toe $15-18(\bar{x}=16.9, \mathrm{SD}=$ 0.90); lamellae beneath fourth toe 31-34 $(\bar{x}=32.3, \mathrm{SD}=1.17)$, smooth, divided toward outer edge for basal third of third and fourth digits.

DETAILS of holotype: Adult female; size $69.0 \mathrm{~mm}$ SVL; distance from axilla to groin $36 \mathrm{~mm}$; distance from forelimb to snout $27 \mathrm{~mm}$; hindlimb length $25.5 \mathrm{~mm}$; tail length $89 \mathrm{~mm}$, regenerated. Midbody scale rows 40; dorsal scale rows 75 ; dorsal scales of fourth finger 11/10; lamellae of fourth finger $18 / 18$; dorsal scales of fourth toe $18 / 17$; lamellae of fourth toe 31/31.

osteology: Premaxillary teeth $11(n=$ $8)$; presacral vertebrae 29 ; postsacral vertebrae $48-50(n=2)$; phalangeal formula for 


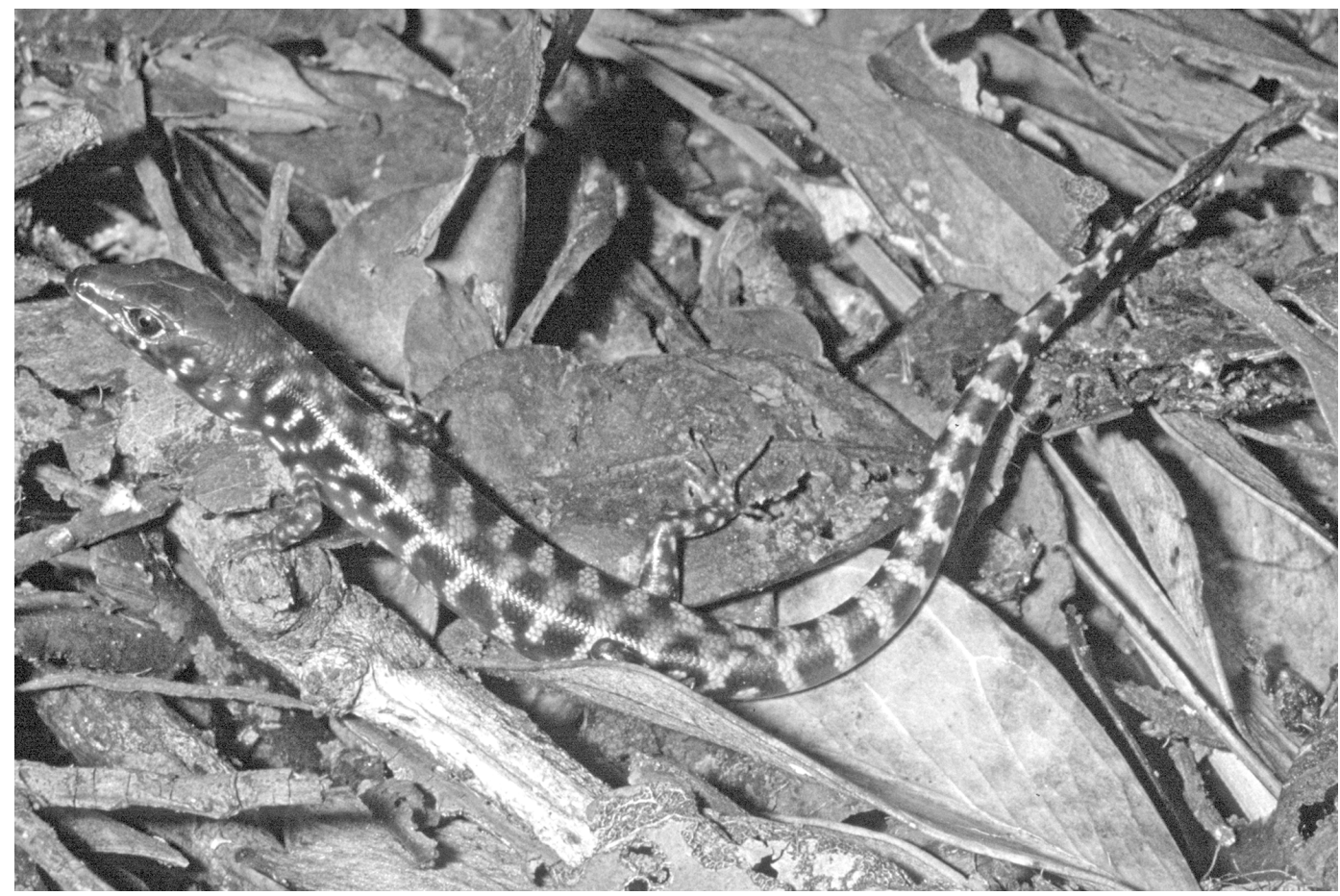

Figure 3. Juvenile Kanakysaurus zebratus, n. sp. (ams R167223), in life.

manus and pes 2.3.4.5.3 and 2.3.4.5.4, respectively; 2 pairs of mesosternal ribs contacting mesosternum.

COLOR AND PATTERN: Adult females (Figure 2): Dorsal surface mid- to dark brown with broad black markings (average 4-5 scales wide at middorsum), running transversely or obliquely across body to form a network pattern of alternating narrow light and wide dark bars that extend to side of body. Dark lateral markings bold over most of lateral surface and only becoming lighter in tone approaching venter, area between forelimb and ear opening predominantly black with scattered paler blotches. Dorsal surface of head and nape dark brown, and mainly unmarked; face similar but with dark central markings on primary and lower secondary temporal scales, posterior labial scales, and lower labials; rostral, nasal, and first lower labial scales noticeably darker than adjacent head scales. Dark markings of lower labials extending to adjacent chin scales but varying in extent and intensity from bold to obscure, remainder of throat area gray with pale blotches, pale markings near forelimbs forming a transverse blotch across throat that is bordered behind by a dark transverse bar just in front of forelimbs (continuous with dark lateral markings on side of neck), which defines posterior edge of throat pattern.

Adult males: Similar to adult females but with dark dorsal and lateral bars being narrower (3-4 scales wide), lighter in tone, and less well defined; and dark markings on face and throat being gray and poorly defined.

Subadults and juveniles (Figure 3): Dorsal and lateral surfaces of body and tail similar in overall pattern to those of adult females in having a pattern of broad dark bars but with light interspaces of body being much paler and those on tail cream to nearly white. Dark markings of throat usually well defined and contrasting with lighter markings in this area (duller and more suffused in AMs R167241), giving a distinct marbled pattern. 


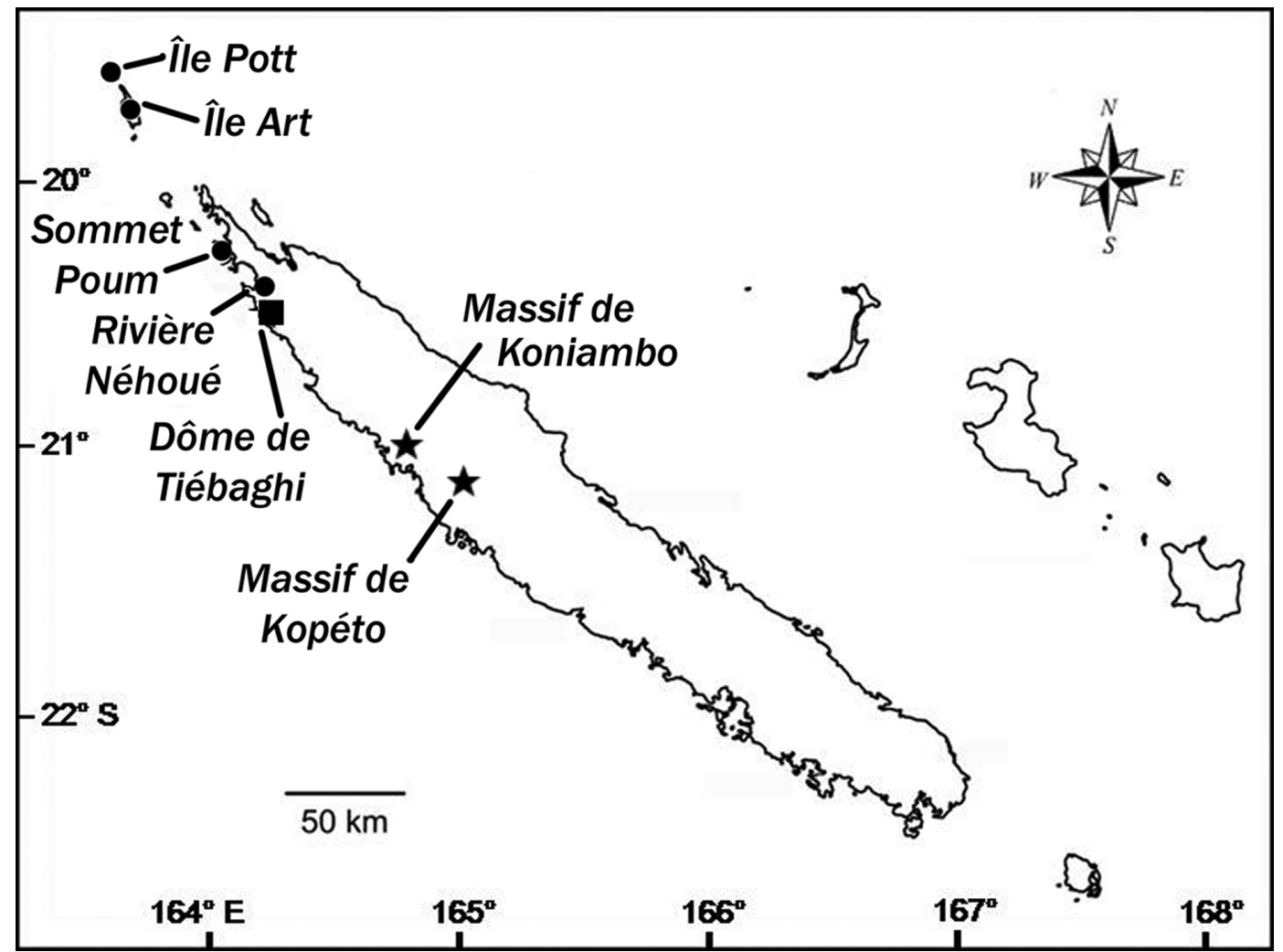

Figure 4. Distribution of Kanakysaurus zebratus, n. sp. (stars), K. viviparus (circles), and K. viviparous + K. sp. (square) in northwestern New Caledonia.

\section{Distribution and Biology}

Kanakysaurus zebratus is currently known only from two locations on the northwestern coast of the Grande Terre of New Caledonia (Figure 4): the upper parts of the ultramafic Massif de Kopéto, south of the Pouembout Valley; and the upper parts of Massif de Koniambo north of the Pouembout Valley.

On Kopéto the species has been found at seven localized sites on the massif over a range of approximately 7.0 by $3.5 \mathrm{~km}$ and an altitudinal range of $480-860 \mathrm{~m}$. At four of the sites the habitat comprises sparse maquis shrubland on a laterite cuirasse surface (Figure 5). Woody shrubs 1-3 m high dominate this vegetation formation, with ground cover consisting largely of leaf litter and rocks. At the remaining three sites the habitat is maquis shrubland on outcropping and eroding peridotites (Figure 6). The woody vegetation at these sites is generally taller and more continuous, and there is a denser ground layer of sedges and ferns. Of the 17 individuals found, three were located during the day as they sheltered beneath large, loose rocks on the cuirasse surface (Figure 5); the remaining 14 were trapped. No active skinks were observed, either by day or night. However, some level of diurnal activity must occur because one of the trapped skinks was captured in a boulder pile between 1030 and 1730 hours on an overcast, showery day.

On Koniambo the species has been located at only a single site in Gymnostoma-dominated closed forest at $700 \mathrm{~m}$. Four individuals were 


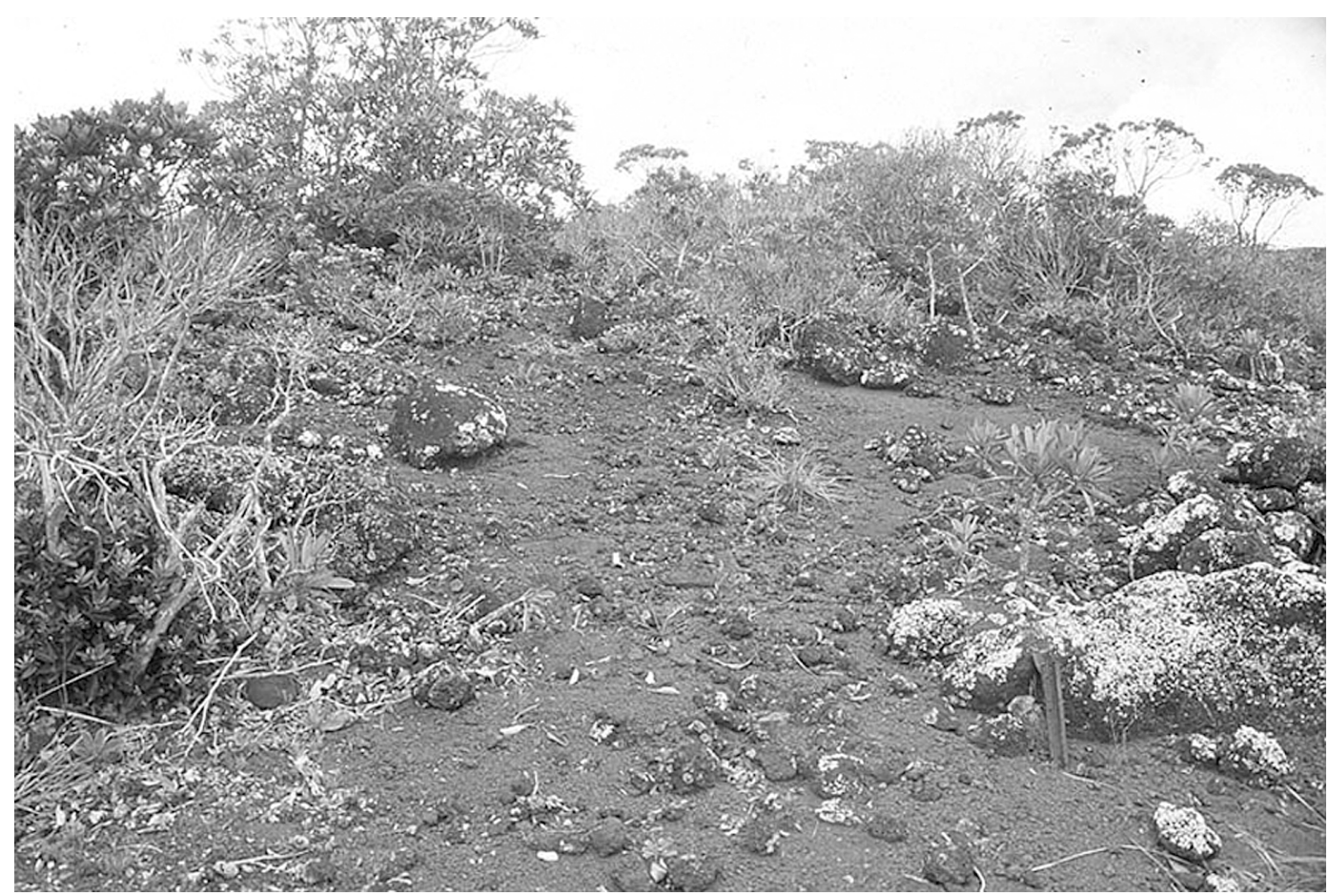

Figure 5. Sparse maquis on cuirasse habitat of Kanakysaurus zebratus, n. sp., on Mount Tiaoué, Massif de Kopéto. One skink was found beneath the boulder at left of center.

recorded (one observation and three trap captures); all were from a small area of rocks in a boulder bank in the forest. None was collected from adjacent forest habitat away from the boulder bank, although a number of Marmorosphax tricolor (Bavay) were recorded.

Current information is inadequate to define the primary habitat for Kanakysaurus zebratus because of the small number of animals found. Although it has the appearance and behavior of a cryptozoic species with high moisture requirements, it has not been found in primary closed-forest habitats. It is remarkable that it has not been recorded from various remnants of high-elevation montane forests on the summits of either the Massif de Kopéto or Massif de Koniambo where Marmorosphax tricolor is abundant. Marmorosphax tricolor and Kanakysaurus zebratus are broadly sympatric on the summit of Massif de Kopéto and both occur in maquis cuirasse habitats; however, despite their general similarity in morphology and habit, $M$. tricolor and $K$. zebratus have not yet been recorded syntopically, perhaps because of some subtle difference in their ecology and habitat. It is interesting to note that the species was not recorded during trapping undertaken in dense Gleichenia fernlands on laterite soils even though the thick vegetation and litter provide a suitably dark and humid environment.

Other lizard species recorded in the maquis shrubland habitat of Kanakysaurus zebratus on Massif de Kopéto include Caledoniscincus atropunctatus (Roux), C. austrocaledonicus (Bavay), C. festivus (Roux), Lioscincus maruia Sadlier, Whitaker \& Bauer, L. nigrofasciolatum (Peters), L. vivae Sadlier, Bauer, Whitaker \& Smith, Marmorosphax tricolor (Bavay), Tropidoscincus boreus Sadlier \& Bauer, Bavayia sp., Eurydactylodes vieillardi (Bavay), and Rhacodactylus auriculatus (Bavay). 


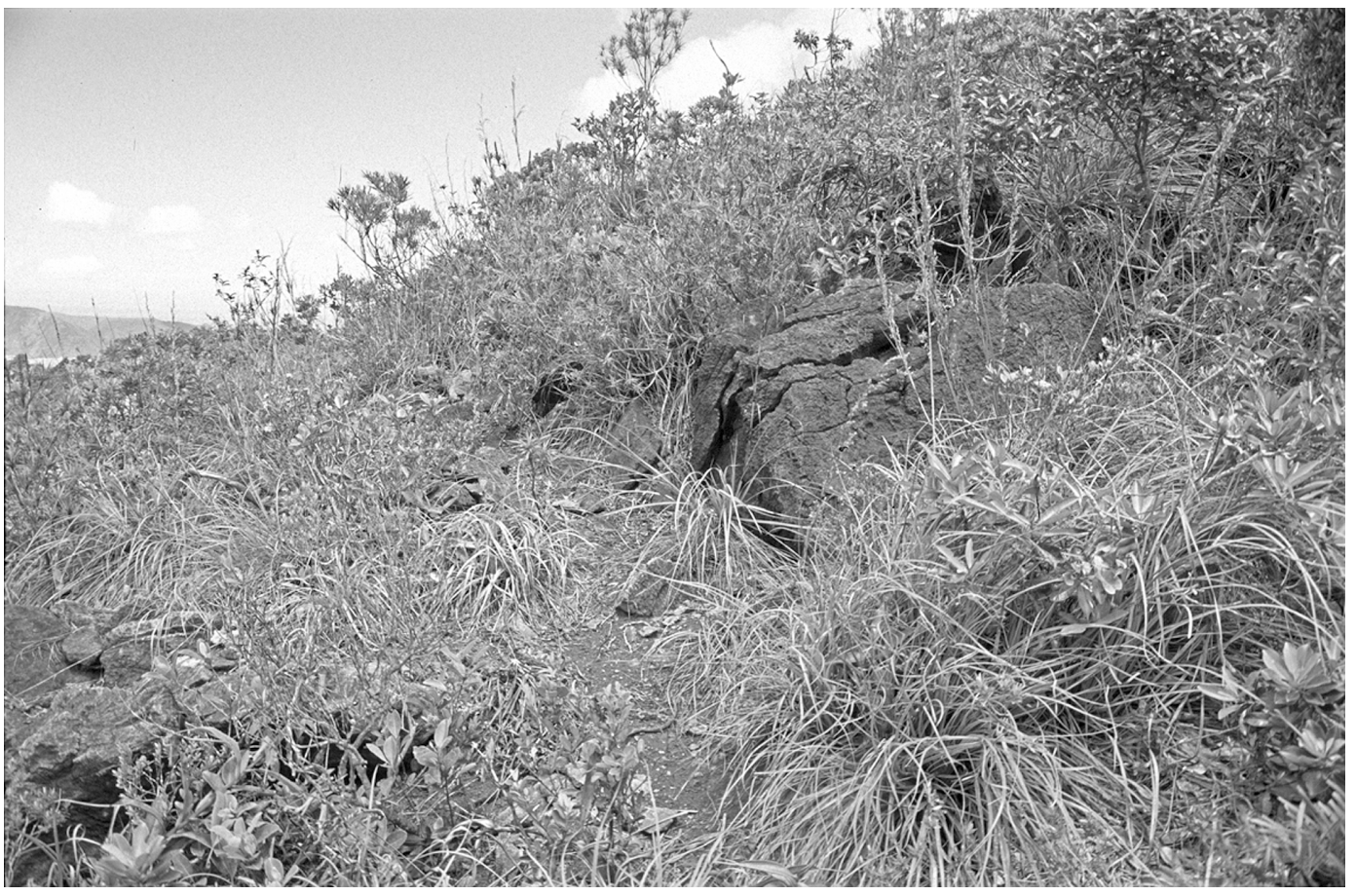

Figure 6. Maquis on peridotite habitat of Kanakysaurus zebratus, n. sp., at Mount Vert, Massif de Kopéto. One skink was captured in a trap set among these outcrops.

Kanakysaurus viviparus Sadlier, Smith, Bauer \& Whitaker, 2004

At the time of its initial description, Kanakysaurus viviparus was known from just four populations: Ille Art and Île Pott in the Îles Belep, Rivière Néhoué, and Dôme de Tiébaghi (Sadlier et al. 2004). Recent field research on Sommet Poum, $28 \mathrm{~km}$ north of Rivière Néhoué, in the far north of Grande Terre, recorded a new population of $K$. viviparus at Paevala on the northern end of the summit plateau.

MATERIAL EXAMINED (7 specimens): AMs R167775 (18 September 2006), AMS R167776 (19 September 2006), 20 14' 57" S, $164^{\circ} 01^{\prime} 33^{\prime \prime} \mathrm{E}$, maquis shrubland on cuirasse; AMs R167778 (17 September 2006), 20 15' $02^{\prime \prime} \mathrm{S}, 164^{\circ} 01^{\prime} 39^{\prime \prime} \mathrm{E}$, maquis shrubland on cuirasse; AMs R167777 (18 September 2006), AMs R167781 (24 September 2006), $20^{\circ} 14^{\prime}$ $53^{\prime \prime} \mathrm{S}, 164^{\circ} 01^{\prime} 34^{\prime \prime} \mathrm{E}$, closed forest; AMs
R167779 (24 September 2006), $20^{\circ} 14^{\prime}$ $45^{\prime \prime} \mathrm{S}, 164^{\circ} 01^{\prime} 34^{\prime \prime} \mathrm{E}$, closed forest; all specimens collected by A. H. Whitaker and V. A. Whitaker.

In morphology and coloration the specimens from Sommet Poum conformed closely to the original description for $K$. viviparus (Table 1).

On Sommet Poum Kanakysaurus viviparus was found at several sites across a range of about $800 \mathrm{~m}$ between 300 and $340 \mathrm{~m}$ elevation. The plateau surface is lateritic cuirasse almost entirely covered with maquis vegetation, the density and height of which varies from essentially bare boulder or pebble surfaces to impenetrable shrubland (height to $4 \mathrm{~m})$. At Paevala there are small, isolated closed-forest patches (tree height 6-10 m), clearly remnants of what was once more widespread forest cover. The skinks were abundant in the closed forest remnants, living in deep boulder banks, beneath loose stones 
and in deep accumulations of leaf litter. They were also present in lesser numbers in boulder areas beneath maquis shrubland. The closed-forest habitat occupied at Paevala is similar to that they inhabit on Île Art and at Dome de Tiébaghi. The maquis cuirasse habitat is unlike any other site where $K$. viviparus occurs but is very similar to that occupied by K. zebratus on Massif de Kopéto.

\section{Molecular Phylogenetics}

The monophyly of Kanakysaurus inclusive of $K$. zebratus is strongly supported by the combined analysis of the ND2 and RAG1 data (MP bootstrap 100\%, posterior probability 1.00). Earlier data showed that the Dôme de Tiébaghi population of $K$. viviparus is genetically distinct from those on the Iles Belep and at Rivière Néhoué, but it was conservatively included within that species (Sadlier et al. 2004). Adding the new data from $K$. zebratus and from the Sommet Poum population of $K$. viviparus to the genetic data set reveals two clades within Kanakysaurus (Figure 7), one comprising the populations of K. viviparus from Rivière Néhoué, Sommet Poum, and the Îles Belep, as well as two individuals from the Dôme de Tiébaghi, which is strongly supported (MP bootstrap 100\%, posterior probability 1.00), and the other including populations of $K$. zebratus from the Massif de Kopéto and Massif de Koniambo and additional specimens from Dôme de Tiébaghi. However, this latter sister-group relationship is not well supported (MP bootstrap $83 \%$, posterior probability 0.79 ). Sequence difference between Kanakysaurus viviparus and $K$. zebratus is $7.9 \pm 1.1 \%$, whereas that between $K$. zebratus populations from Kopéto and Koniambo and the three specimens from Tiébaghi (Figure 7: K. sp.) that constitute their sister-group is $1.4 \pm 0.2 \%$.

\section{DISCUSSION}

\section{Status of Dôme de Tiébaghi Kanakysaurus}

The low level of genetic divergence between $K$ zebratus and the clade of Dôme de Tiébaghi specimens constituting its sister-group su- perficially suggests that they are conspecific, with Tiébaghi representing a relatively distant $(85 \mathrm{~km})$ northern population. However, the Tiébaghi specimens (all males) have both narrow (1-2 scales wide) and moderately broad (3-4 scales wide) transverse dorsal markings (versus 3-4 in male $K$. zebratus) and lack the intensity and continuity of breadth of the dark transverse bars seen in $K$. zebratus. Further, they do not share the elevated number of dorsal scale rows that characterizes both populations of $K$. zebratus (66-69 versus 72-81). Indeed, these specimens from Tiébaghi are morphologically indistinguishable from typical $K$. viviparus (Table 1). Thus these individuals are clustered with $K$. zebratus on the basis of mitochondrial DNA data and with $K$. viviparus on the basis of diagnostic morphological features (the RAG1 data alone were equivocal in the placement of these specimens). We suggest that this conflict in the data may be reflective of past mitochondrial introgression or that the problematic Tiébaghi specimens may share plesiomorphic morphological features with $K$. viviparus even though they share derived sequence characteristics with $K$. zebratus. Pending further investigation of Dôme de Tiébaghi populations, we refrain from assigning these specimens to species and refer to them simply as Kanakysaurus sp.

\section{Conservation Status}

Detailed information on population sizes or reproductive effort within generations is lacking for most New Caledonian lizard species, so the first-level criterion used in assessing conservation status is the extent of distribution-species with restricted ranges usually are those most susceptible to threats. We have here used a modified area of occupancy index adjusted for the total area of New Caledonia (Sadlier and Bauer 2003) wherein a species represented by a single locality record $(0.5 \%$ or less of total landmass) is considered eligible to be placed in the Endangered category, or higher, in the presence of threats to the area of occupancy or extent and quality of habitat.

On the Massif de Kopéto Kanakysaurus ze- 


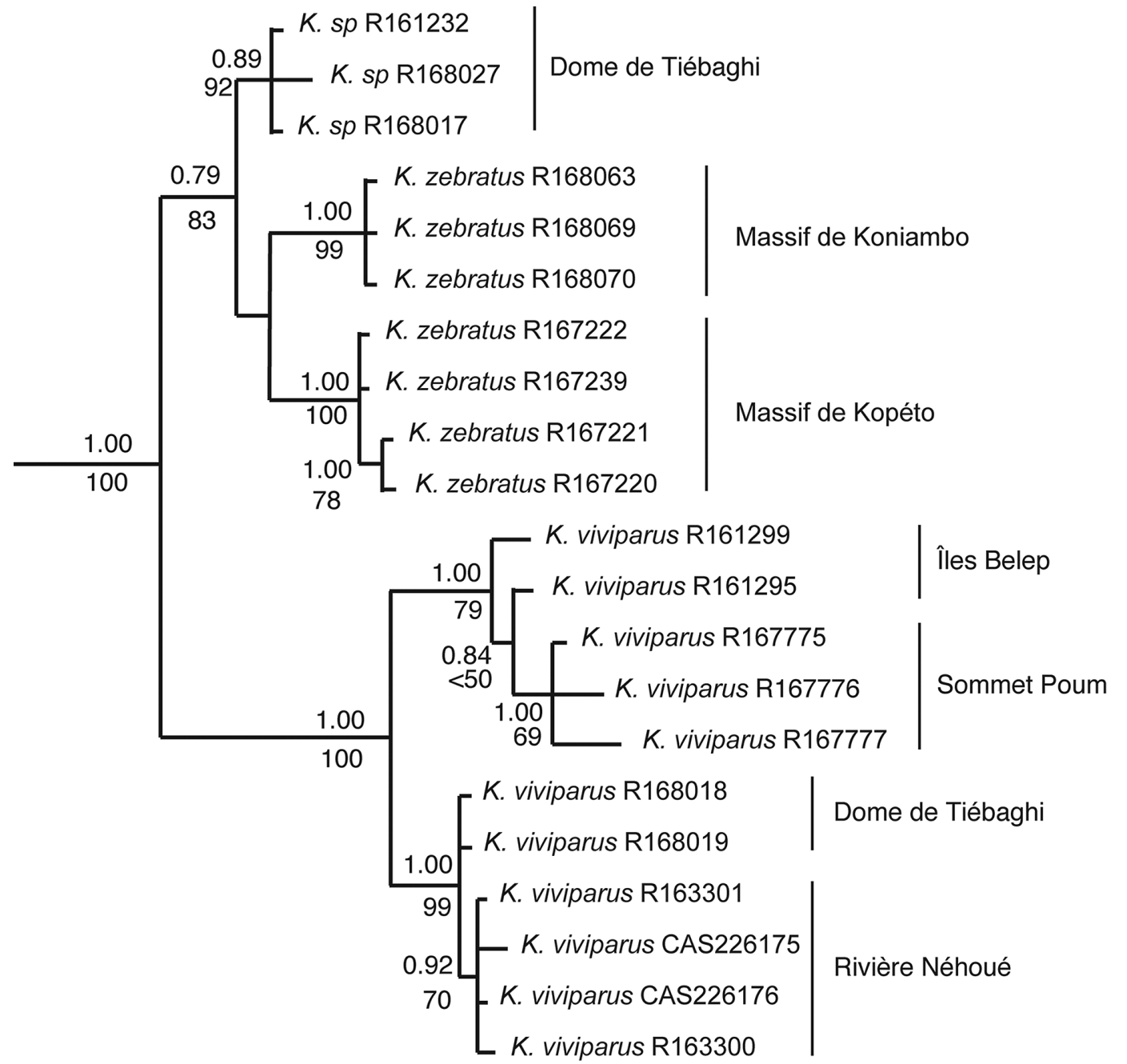

Figure 7. Phylogenetic relationships among populations of Kanakysaurus. Bayesian topology is shown with posterior probabilities above the branches and MP bootstraps below. For outgroups see Smith et al. (2007).

bratus is currently known only from maquis habitat on the upper parts. The opencast nickel mine operating on the summit of Kopéto is one of the most sophisticated and intensive in the region. With the entire area of the mountain above $700 \mathrm{~m}$ elevation held under mining lease and plans to extend the open pits in the near future there will be a substantial reduction in the extent of the relatively undisturbed maquis habitat of $K$. zebratus on the upper part of the massif and in particular of that on the cuirasse surfaces. To some ex- tent mitigating this potential habitat loss is the fact that the mine site is very strictly controlled and managed, and access is restricted. This minimizes the risk to any remaining areas of habitat from threats such as wildfires and human disturbance that are important elsewhere in New Caledonia. On the Massif de Koniambo the situation is quite different: the species appears to have a much more restricted distribution, being known from a single location that is in close proximity to the main access route to the mine area. Despite 
investigation of other habitats on the summit area of the massif, including maquis on cuirasse surfaces, no additional specimens were located.

Because of its apparently extremely restricted range and the threats to its preferred habitat at each location, Kanakysaurus zebratus currently meets the criteria for classification as Endangered both under IUCN (2001) and our modified (Sadlier and Bauer 2003) criteria, and we recommend that conservation of the species on each massif be treated as an equally high conservation priority. To fully assess the importance of the sites from which it is known, and to put in context the impact of proposed mine expansion at both sites on the conservation status of this species, further field research is required to determine its distribution in the region. South of the Pouembout Valley this includes investigation of the contiguous peak of Paéoua, immediately to the east of Kopéto, and the two lower plateaus to the west, Col de Tiaoué and Plateau de Tia, and north of the Pouembout Valley this should concentrate on additional survey work on Koniambo and the massifs to the north, including Taom and Kaala.

The discovery of the new population of Kanakysaurus viviparus at Sommet Poum would normally lead to an improvement in its conservation status. However, because there are advanced plans for mining the entire summit plateau that will result in the removal of all known habitat for this species on the massif, its conservation status must remain Endangered. Similarly, an expansion of mining activity at the Dôme de Tiébaghi is proposed in the near future, resulting in a high level of conservation significance for this population (and Kanakysaurus sp.).

\section{ACKNOWLEDGMENTS}

We thank the Province Nord authorities for permission to conduct herpetological research in northern New Caledonia and to collect specimens, acknowledging in particular the ongoing support of Jean-Jérôme Cassan, Direction du Développement Économique et de l'Environnement (DDE-E), Koné. Specimens of Kanakysaurus zebratus were collected under permits No. 60912428-2006/JJC and 60912-1930-2007/JJC, and those of $K$. viviparus under permit 60912-3109-2006/JJC, all issued by DDE-E. The initiative of Société Le Nickel (SLN) and Koniambo Nickel SAS (KNS) in commissioning the fieldwork on the Massif de Kopéto and Sommet Poum, and on Koniambo, respectively, is commended. We are grateful to Bernard Pelletier, Jean-Marie Martinet, Philippe Bains, and Jean-Pierre Perrier of SLN and Denis Poignonec of KNS for variously supporting the fieldwork and for on-site logistical assistance. Hervé Jourdan, of Institute de Recherche pour le Développement, Nouméa, again provided important logistical backing for our research in New Caledonia. Anouk Mututantri prepared the illustrations of the head shields (Figure 1) and Hannah Finlay the map (Figure 4). Vivienne Whitaker assisted with all aspects of the fieldwork on Kopéto and found the first specimen of this new species. We thank Christopher Austin and Patrick Couper for their constructive comments on the manuscript.

\section{Literature Cited}

Bauer, A. M., and T. Jackman. 2006. Phylogeny and microendemism of the New Caledonian lizard fauna. Pages 9-14 in M. Vences, J. Köhler, T. Ziegler, and W. Böhme, eds. Herpetologica Bonnensis II, Proceedings of the 13th Ordinary General Meeting of the Societas Europeae Herpetologica. Zoologisches Forschungsmuseum Alexander Koenig, Bonn.

Bauer, A. M., T. Jackman, R. A. Sadlier, and A. H. Whitaker. 2006a. A new genus and species of diplodactylid gecko (Reptilia: Squamata: Diplodactylidae) from northwestern New Caledonia. Pac. Sci. 60:125$135,1 \mathrm{pl}$.

2006b. A revision of the Bavayia validiclavis group (Squamata: Gekkota: Diplodactylidae), a clade of New Caledonian geckos exhibiting microendemism. Proc. Calif. Acad. Sci. 57:503-547.

IUCN. 2001. IUCN Red List categories and criteria: version 3.1. IUCN Species Sur- 
vival Commission. IUCN, Gland, Switzerland, and Cambridge, United Kingdom.

Jaffré, T., P. Morat, J.-M. Veillon, F. Rigault, and G. Dagostini. 2001. Composition et charactéristiques de la flora indigène de Nouvelle-Calédonie. Inst. Rech. Dev. Doc. Sci. Tech. II 4, Nouméa.

Mittermeier, R. A., P. Bouchet, A. M. Bauer, T. Werner, and A. Lees. 1999. New Caledonia. Pages 366-377 in R. A. Mittermeier, N. Myers, and C. G. Mittermeier, eds. Hotspots: Earth's biologically richest and most endangered terrestrial ecoregions. CEMEX, Mexico City.

Mittermeier, R. A., T. B. Werner, and A. Lees. 1996. New Caledonia-a conservation imperative for an ancient land. Oryx 30:104-112.

Myers, N. 1988. Threatened biotas: "Hot spots" in tropical forests. Environmentalist $8: 187-208$.

- 1990. The biodiversity challenge: Expanded hot-spot analysis. Environmentalist 10:243-256.

Myers, N., R. A. Mittermeier, C. G. Mittermeier, G. A. B. Da Fonseca, and J. Kent. 2000. Biodiversity hotspots for conservation priorities. Nature (Lond.) 403:853858.

Sadlier, R. A. 1986. A review of the scincid lizards of New Caledonia. Rec. Aust. Mus. 39:1-66.

Sadlier, R. A., and A. M. Bauer. 2003. Conservation status of endemic New Caledonian lizards - an assessment of the distribution and threats to the species of lizards endemic to New Caledonia. http://www.amonline.net.au/herpetology/ research/lizards_conservation_intro.htm.

Sadlier, R. A., and G. Shea. 2004. Étude faunistique spécifique herpétofaune sur le site minier Goro Nickel proposé. Unpubl. report to Goro Nickel S.A., Australian Museum Business Service, Sydney. (Available from the authors.)
2006. Étude de l'herpetofaune de quatre reserves speciales du Grand Sud de la Nouvelle Caledonie et propositions d'orientations de measures de conservation -Réserve spéciale botanique Forêt Nord, Réserve spéciale botanique Cap N'Doua, Réserve spéciale botanique Pic du Pin, et Réserve spéciale botanique Pic du Grand Kaori. Unpubl. report to Direction des Resources Naturelles, Province Sud, Nouméa. Australian Museum Business Service, Sydney. (Available from the authors.)

Sadlier, R. A., S. A. Smith, A. M. Bauer, and A. H. Whitaker. 2004. A new genus and species of live-bearing scincid lizard (Reptilia: Scincidae) from New Caledonia. J. Herpetol. 38:320-330.

- In press. Three new species in the genus Marmorosphax (Squamata: Scincidae) from New Caledonia. Zoologica Neocaledonica 6. Mém. Mus. Natl. Hist. Nat.

Smith, S. A., R. A. Sadlier, A. M. Bauer, and T. Jackman. 2007. Molecular phylogeny of the scincid lizards of New Caledonia and adjacent areas: Evidence for a single origin of the endemic skinks of Tasmantis. Mol. Phylogenet. Evol. 43:1151-1166.

Taylor, E. H. 1935. A taxonomic study of the cosmopolitan scincoid lizards of the genus Eumeces with an account of the distribution and relationships of its species. Univ. Kans. Sci. Bull. 23:1-643.

Whitaker, A. H., R. A. Sadlier, A. M. Bauer, and V. A. Whitaker. 2004. Biodiversité et situation de conservation dans Îles habitats menacés et restreints du nord-ouest de la Nouvelle Calédonie. Rapport non publié de Whitaker Consultants Limited pour la Direction du Développement Économique et de l'Environnement-Province Nord-Koné-Nouvelle Calédonie. (Available from the authors.) 